\title{
Specifics of Making Ceramic Vessels of the Shepilevsky Culture \\ (Based on the Materials of the Zaostrovka-2 Settlement)
}

\author{
Yuliya A. Titova* \\ Siberian Federal University \\ 79 Svobodny, Krasnoyarsk, 660041, Russia
}

Received 03.02.2015, received in revised form 11.03.2015, accepted 02.04.2015

The article presents the results of the study of the pottery making techniques of the Shepilevsky culture in the Late Bronze Age based on the materials of the Zaostrovka-2 settlement. The basis of the study of the ceramic technology is a historical-cultural approach and methodology of A.A. Bobrinsky. The study of all stages of the ceramic production showed predominance of mixed skills that reflect the complex interaction of ancient people in Central Siberia, where there was a formation of the Shepilevsky archaeological culture.

Keywords: archaeology, ceramics, Central Siberia, Late Bronze Age, Shepilevsky culture, pottery technology, historical-cultural approach, raw material, moulding compounds, designing, shaping, surface treatment, firing.

Research area: history.

\section{Introduction}

The study of ceramic production is one of the current trends in modern archaeology. This is primarily due to the fact that ceramics is the most popular archaeological material and it provides ample opportunities for cultural interpretation. In the 60 's of the $20^{\text {th }}$ century the ceramic production technology becomes a subject of a separate study in the works of A.A. Bobrinsky. He revealed a historicalcultural approach, in which the production of ceramics is seen as a system of sustained and interconnected skills and methods of work that represent a specific sequence of operations. According to A.A. Bobrinsky, educible, sustained (substrate) work skills can produce historical-cultural reconstruction based on the study of the ancient pottery technology (Bobrinsky, 1978, 1999).

The main focus of the article is to study the ancient technology of pottery making performed by carriers of the Shepilevsky cultural tradition based on the Zaostrovka-2 settlement, which will trace the formation of ceramic production of the autochthonous inhabitants in Siberia and identify its main directions.

The basis of the study of ceramics is the methodology of A.A. Bobrinsky, which is based on the use of a binocular microscopy and consists of:

(C) Siberian Federal University. All rights reserved

* Corresponding author E-mail address: abdulia@mail.ru 
1) study of traces of the potter's work by fresh fractures using the MBS-10 microscope;

2) study of traces of the potter's work observed on surfaces of vessel;

3) comparing with the reference collection.

\section{Main point}

This article presents some results of the study of a ceramic collection found in the Zaostrovka-2 settlement as a result of archaeological excavations in 2006 (Abdulina, Mandryka, 2007: 168-175). The settlement is located near Kazachinsky rapid, on the left bank of the Yenisei River. The monument is located $230 \mathrm{~km}$ North from Krasnoyarsk on a 14-17-meter terrace of the right bank of the Yenisei River, $150 \mathrm{~m}$ northeast of the right bank of the Zaostrovka branch and belongs to the UstShilkinsky archaeological microdistrict. The settlement consists of four rows of housing pits. In July 2006, after excavating 90 square meters archaeologists found the sixth dwelling from the second row that, according to all the signs, refers to the Shepilevsky archaeological culture of the Late Bronze Age (Mandryka 2008: 140-145).

The ceramic collection consists of 977 fragments of ceramic items, among them there are 102 fragments of rims of 47 vessels, as well as eyelets and walls with edge rolls of 13 smudge pots. The ceramic material is found both inside the dwellings and outside, fully matches up typologically, and is partially reconstructed. The collection includes can-shaped (40), pot-shaped (5) and cup-shaped (2) vessels.

Ceramic vessels have a characteristic ornament only in the upper third of the vessel's area with decoration of edges and the use of horizontal motifs. Based on the composition of ornamentation of the vessels three variants can be allocated within a single ceramic type:

1) a vessel's rim is thickened with a flagellated stick-on edge roll that is dissected with finger tucks. The composition can be complemented by a row of nail markings under the edge roll (Fig. 1, $1-8,11$ vessels);

2) a rim is straight, gradually thickened by a stick-on band. It has one to four rows of finger tucks or markings. Sometimes a straight edge is also dissected with finger tucks (Fig. 1, 9-23; 22 vessels);

3) a rim is teardrop-shaped in section with two thin stick-on edge rolls on the outer edge that are dissected with the nail dimples (Fig. 1, 24, 25; 2 vessels).

Besides vessels decorated with different finger impresses, the ceramic collection also features other individual variants of vessel ornamentation:

4) a pot with a poorly shaped throat that is marked by two horizontal rows of vertical impresses of a straight ornament making tool with a sharp working edge (vessel No. 2 in the collection inventory). The vessel is roundbottomed with a slightly flattened bottom (Fig. 1, 27).

5) a straight edge of the rim is dissected with impresses of a straight smooth ornament making tool. Under the rim there are two horizontal rows of dimple markings (vessel No. 3 in the collection inventory), below there is a row of inclined nail markings (Fig. 1, 28);

6) a vessel's edge thickened by a wide band is ornamented with three horizontal rows of triangular notches by a smooth ornament making tool (vessel No. 14 in the collection inventory). The band is emphasized by a sagging horizontal smooth groove (Fig. 1, 26);

7) a pot with an ornament in the form of thin lines forming a diamond-shaped grid (vessel No. 38 in the collection inventory) on a profiled throat of the vessel (Fig. 1, 29).

In the collection there are eight vessels with no ornament (Fig. 1, 30-32).

Ceramic eyelets and walls with stick-on edge rolls (Fig. 1, 34-42) from different vessels (total 

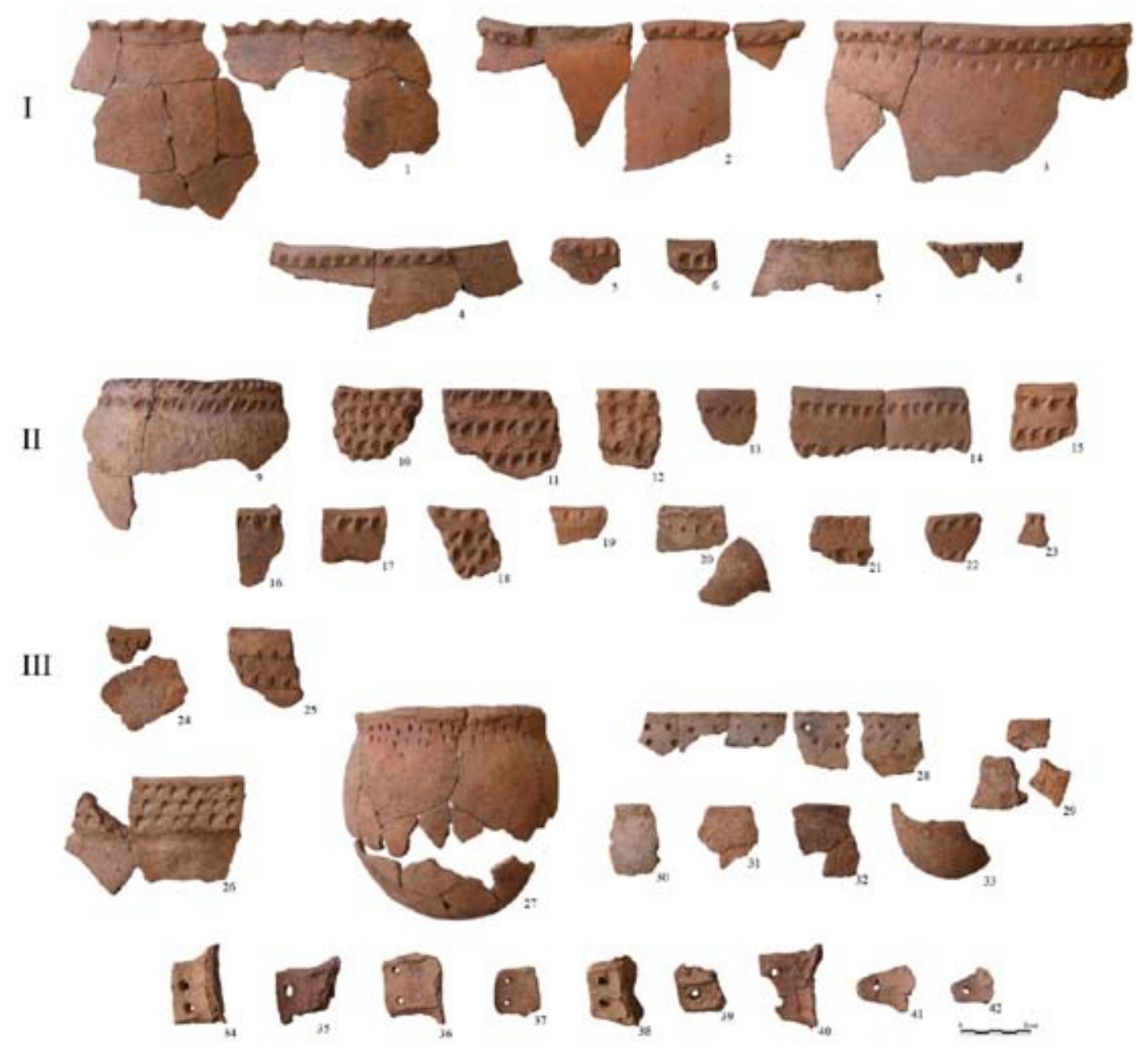

Fig. 1. Ceramic vessels of the Zaostrovka-2 settlement based on excavation materials in 2006

13 pcs) show that there are smudge-vessels in the collection. Typologically, eyelets are divided into three groups: 1) rectangular-shaped with two holes (8 pcs), 2) tongue-shaped with one hole (2 pcs), and 3) tubular with a round hole (1 pc).

The condition of the archaeological ceramics (its fragmentation) from the settlement makes it possible to obtain certain information about the principles of selection of the raw material, its preparation, making of moulding compounds, and general information about the design, surface treatment and shaping of products.

Principles of selection of the raw material. A raw material was exclusively those kinds of clay that, according to the degree of ferruginization and the presence of natural sand, can be divided into two main groups: ferruginous clay, a predominant type of raw materials, and non-ferruginous clay, mainly as a supplement to the ferruginous one. According to the degree of ferruginization, sand content and a nature of sand these clays are divided into 7 subtypes (Titova, 2010: 81-83). As a result of the study of ceramics samples it was found that the use of a mixture of two clays as the raw material was very characteristic for the ceramic production. The main clay was always ferruginous, the second type, non-ferruginous clay was introduced in a dry or a slightly moist state and is present in the vessels as 


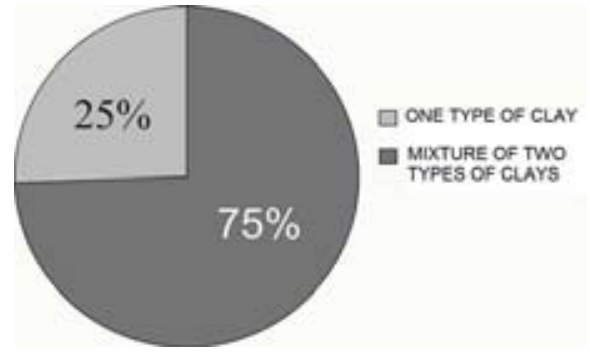

Fig. 2. Diagram of the ratio of vessels made of one type of clay and of a mixture of two types of clays

small lumps of the size of $3 \mathrm{~mm}$. Such a technique is seen in 35 vessels (75\%).

Such mixed skills of selection of the plastic raw material is a sufficient evidence that potters, i.e. the carriers of these skills, during their activities were forced to adapt to new sources of raw materials, which typically occurred when they migrated (Bobrinsky, 1999: 67). In this case, we have a reason to talk about the "... 'transformation' of such skills into the traditional norms - by the massive presence of ceramics with mixed selection skills" (Bobrinsky, 1999: 71).

The remaining 12 vessels ( $25 \%$ ) were made of one type of clay, mainly ferruginous, and only one vessel from the collection was made of non-ferruginous clay. Interestingly, the vessel made of non-ferruginous clay is the one with a personalized decoration in the form of two horizontal belts of dimples and nail markings under them (Fig. 1, 28).

\section{Preparation of raw materials.}

When studying skills of preparation of raw materials it was found experimentally that the main ferruginous clay was used in a naturally moist state, but the non-ferruginous clay was introduced in a dry, naturally granulated state. In nine cases, the second (non-ferruginous) type of clay was introduced in a wet state, which is reflected in its characteristic location on the cleaved surface in the form of thin lenses and spreads. In one pot, both types of clay are present in a dry state, which is characterized by the presence of salient lumps. Probably, the non-ferruginous clay could be produced in the territory of the settlement during construction of dwellings, because in geological terms, it is represented as a layer of a dense, fine-grained loam, in which the dwellings were deepened.

\section{Preparation of moulding compounds.}

The moulding compounds of vessels consisted of the following artificially introduced components:

1. Landwaste - mineral materials of an artificial form ( $80 \%, 38$ vessels). In pottery of the settlement this non-plastic material that increases fire resistance of products is represented by the gneissic-granite rocks - sharp-edged crystals of quartz, feldspar and mica flakes can be seen on a fresh shear. Inclusion sizes range from $0.2 \mathrm{~mm}$ to $3.0 \mathrm{~mm}$. In the bulk of the collection vessels landwaste is presented at a high concentration, from 1:2 to $1: 5$ (57\% of all vessels) in some vessels considerably smaller concentration is observed: 1:8 and even 1:9 (23\%).

2. Chamotte - crushed fragments of disused dishes $(57 \%, 27$ vessels). This non-plastic material, like landwaste, increases fire resistance of vessels. Basically, chamotte is the small $1 \mathrm{~mm}$ inclusions that also consist of the second type of clay, gneissic-granite landwaste and, in some cases, chamotte.

3. Organics (93\%, 44 vessels). It is the most difficult additive in terms of identification and the purpose of use. The organic solution with the inclusion of a solid component was introduced into the moulding compound, which is characterized by the following features: after firing the organic solutions at the fracture of the crock leave characteristic layering, porosity; white, beige, yellow or brown coating; small voids with a greasy lustre, black thick impregnation; remnants of the unburned organic matter in the form of gray and brown strands, clusters of 
small gray and brown "grains", friable powdery inclusions, etc. In some cases, there are grooved prints of some greatly crushed vegetation. In one vessel we found the presence of a solid type of the organic matter that is characterized by the following features: numerous voids of up to $3 \mathrm{~mm}$ in diameter having a regular shape with rounded edges covered inside by frosted beige coating, without the apparent lustre. The experiments led to the following conclusions. Initially it was assumed that these pores could appear after burning of crushed nuts or berry seeds, however, samples made with these fillers do not cause such voids. The closest in form were the voids in the experimental sample made with the addition of autumn bear faeces mainly consisting of halfdigested, poorly crushed pine nuts (Titova (2), 2012: 83).

As for the recipes of the moulding compounds, A.A. Bobrinsky allocates unmixed (clay and one type of non-clay material) and mixed (clay and two or more non-plastic materials) moulding compounds (Bobrinsky, 1978; 90-91).

\begin{tabular}{|c|c|c|c|c|c|c|}
\hline \multirow[b]{2}{*}{ Ornamentation } & \multicolumn{2}{|c|}{ Raw materials } & \multicolumn{4}{|c|}{ Moulding compounds } \\
\hline & $\begin{array}{l}\text { Mixture of } \\
\text { two clays }\end{array}$ & $\begin{array}{l}\text { One } \\
\text { clay }\end{array}$ & $\begin{array}{c}\text { Landwaste } \\
\text { + organics / } \\
\text { organic solution }\end{array}$ & $\begin{array}{l}\text { Chamotte } \\
+ \text { organic } \\
\text { solution }\end{array}$ & $\begin{array}{c}\text { Landwaste }+ \\
\text { chamotte }+ \text { organic } \\
\text { solution }\end{array}$ & $\begin{array}{l}\text { Organic } \\
\text { solution }\end{array}$ \\
\hline $1^{\text {st }}$ variant & $\begin{array}{l}1,4,5,7,15 \\
24,28,30 \\
36,45\end{array}$ & 13 & $\begin{array}{l}13(1: 6),, 45 \\
(1: 4 / 5)\end{array}$ & $\begin{array}{l}4(1: 4), 28 \\
(1: 6)\end{array}$ & $\begin{array}{l}1(1: 4 ; 1: 8 / 9), 5(1: 4 ; \\
1: 10), 7(1: 6 ; 1: 7), 15 \\
(1: 3 / 4), 24(1: 4 ; 1: 4), \\
30(1: 5 ; ?)\end{array}$ & 36 \\
\hline Quantity & 10 & 1 & 2 & 2 & 6 & 1 \\
\hline $2^{\text {nd }}$ variant & $\begin{array}{l}9,10,16,19, \\
20,21,22, \\
26,32,33,35, \\
39,40,43,44, \\
46,47\end{array}$ & $\begin{array}{l}8,23, \\
25, \\
37, \\
42\end{array}$ & $\begin{array}{l}9(1: 3), 23(1: 2), \\
25(1: 3), 32 \\
(1: 2 / 3), 37(1: 4), \\
39(1: 5), 40(1: 4), \\
42(1: 5), 44(1: 3)\end{array}$ & $\begin{array}{l}21(1: 8), 47 \\
(1: 9)\end{array}$ & $\begin{array}{l}8(1: 8 ; 1: 7), 10(1: 3 ; \\
1: 10), 16(1: 6 ; 1: 6), 19 \\
(1: 9 ; 1: 7), 20(1: 5 ; 1: 6), \\
22(1: 6 ; 1: 9), 26(1: 4 ; \\
1: 7), 33(1: 4 ; 1: 7 / 8), \\
35(1: 8 ; 1: 7), 43(1: 8 ; \\
1: 10), 46(1: 6 ; 1: 8)\end{array}$ & \\
\hline Quantity & 17 & 5 & 9 & 2 & 11 & \\
\hline $3^{\text {rd }}$ variant & 27,34 & & $27(1: 3), 34(1: 4)$ & & & \\
\hline Quantity & 2 & & 2 & & & \\
\hline $\begin{array}{l}\text { Without } \\
\text { ornament }\end{array}$ & $\begin{array}{l}6,11,12,17 \\
18,29\end{array}$ & 31,41 & $\begin{array}{l}6(1: 3 / 4), 11(1: 8), \\
12(1: 3), 18(1: 3)\end{array}$ & $\begin{array}{l}17(1: 10), 41 \\
(?)\end{array}$ & $29(1: 8 ; 1: 9)$ & 31 \\
\hline $\begin{array}{l}\text { Sharpened } \\
\text { dimples }\end{array}$ & & 2 & & & $2(1: 6 ; 1: 7)$ & \\
\hline $\begin{array}{l}\text { Pinholes, } \\
\text { dimples and } \\
\text { nail markings }\end{array}$ & & 3 & & $3(1: 5)$ & & \\
\hline Notches & & 14 & $14(1: 4)$ & & & \\
\hline Grid & & 38 & & & $38(1: 3 ; 1: 5)$ & \\
\hline Total quantity & 35 & 12 & 18 & 7 & 20 & 2 \\
\hline Ratio & $75 \%$ & $25 \%$ & $38 \%$ & $15 \%$ & $42 \%$ & $5 \%$ \\
\hline
\end{tabular}

Fig. 3. Ratio of raw materials and moulding compounds by vessels (numerals indicate the numbers of vessels in the collection inventory; numbers in brackets near the numbers of vessels show the non-plastic materials concentration) 


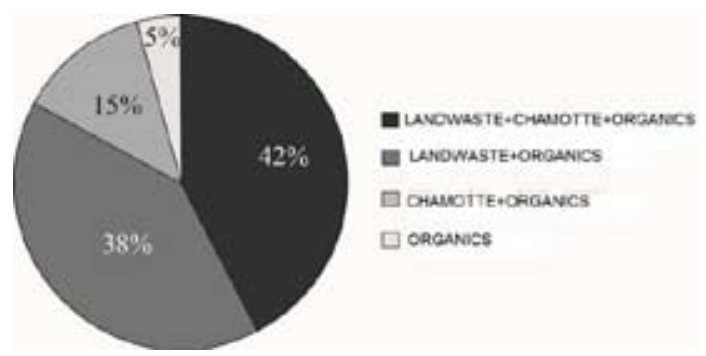

Fig. 4. Diagram of ratio of recipes for moulding compounds by vessels

As a result of the study we found four recipes for making moulding compounds: one of them is unmixed, others characterize different stages of the mixing process.

The settlement's collection virtually has no vessels with unmixed recipes of moulding compounds demonstrating separate skills, and only two vessels have the organic solution in the moulding composition. At the same time, the study suggests three mixed recipes of the moulding compounds:

1) Landwaste + Organics (38\%). At this, landwaste is present mainly in a high concentration $1: 3-1: 4$,

2) Chamotte + Organics (15\%). In 5 vessels that have chamotte in the composition there is the presence of chamotte in chamotte at the high concentration, up to 1:5/6, which may tell of the sustainable chamotte tradition.

3) Landwaste + Chamotte + Organics $(42 \%)$. Such skills of making moulding compounds tell of the mixture of carriers of two traditions of the ceramic production: the tradition to add landwaste into the moulding compound, which is predominant, and the tradition to add chamotte, i.e. the additives, functions of which are the same in ceramics - they increase refractoriness of dishes.

Designing and shaping. The fragmentary of the material only allows us to make the most general conclusions. It was found that residents of the settlement made their vessels from different scraps using two methods of joining - scrappy sticking-on with spiral overlaying (1 vessel) and lumpy unorganized sticking-on (13 vessels). Part of the vessels was made on a mould (10 vessels), which is marked by a characteristic folding inside the vessel and prints, probably, from a leather gasket. Part of them was made in the form of a container ( 2 vessels and one bottom that is non-attributable to a particular vessel), which is evident by prints of unidirectional grooves on the outer surface of the vessel remained presumably from the leather gasket, and also by considerable differences in thickness of vessel's walls, finger impresses resulting from extruding the vessel in the form of a container. Such a technical stage of shaping as knocking-out of vessels is connected with making vessels on a mould. Most vessels were knocked-out with a beater having a vesicular surface that left deep diamond-shaped cells on a surface of the vessels. Cell sizes, when they are definable, could reach $0.2 \times 0.6 \mathrm{~cm}$, $1.0 \times 1.0 \mathrm{~cm}, 0.4 \times 1.0 \mathrm{~cm}, 0.8 \times 1.5 \mathrm{~cm}$. Such skills of shaping by knocking-out vessels with a beater with diamond-shaped notches are evident on 13 vessels, although other vessels also could be made in a similar way, since the surface of all vessels became very smooth after knocking-out. The second method of shaping is also associated with knocking-out, but using a spatula wrapped with a thin twisted cord. Similar skills are recorded only in 2 vessels from the collection, which may indicate a gradual withdrawal from this method of shaping that was popular in the specified area in the Early Bronze Age (Abdulina, 2006: 381). We should also say about the smudge-vessels: their structural elements - eyelets were made by sculptural modelling out of a lump of clay, and then attached to the vessel through a "spike" inserted into a hole in the vessel's wall.

Surface treatment. Surface treatment implies smoothing the vessel walls with fingers. There 
is horizontal and vertical smoothing. On two vessels we can observe smoothing with a comb press-tool, at that in one case it is superimposed over the knocking-out with a beater with wafer cutting.

Firing. Firing of vessels was allegedly carried out on an open fire, as evidenced by their uneven, spotty coloration. We excluded lowtemperature firing because vessels with such kind of firing retain residual plasticity and, when their fragments are placed in water for a day, they either completely dissolve (firing at temperatures of up to 450 degrees) or leave a sediment and then are kneaded with fingers (firing at 650-700 degrees) (Bobrinsky, 1999; 85-94). None of the samples put in the water for a day left sediment. Thus, all the vessels were heat treated. Monochromatic colouring of vessels in fracture may indicate that the effect of the heat was long-term with a gradual drop of temperatures.

\section{Discussion of results}

The correlation of the three variants of ornamentation of pottery with features of the vessel making technology reveals the following regularities.

Vessels with the $1^{\text {st }}$ and $2^{\text {nd }}$ variants of ornamentation show mixed skills of the preparatory stage: the majority of these vessels were made of a mixture of two clays (27 vessels out of 34) and mixed recipes for moulding compounds (33 vessels).

Ceramic vessels with the $3^{\text {rd }}$ variant of ornamentation are made of a mixture of two clays; the moulding compound includes a high concentration of gneiss-granite landwaste (1:3/4) and the organic solution with a solid component (in one case it is likely autumn bear faeces).

All the vessels with single-variant ornamentation show the use of only one type of clay as the raw material. But the compositions of moulding compounds are diverse.
In the composition of the moulding material of a vessel decorated with two horizontal rows of circular impressions (dimple belts) and a number of nail markings we observe the presence of chamotte that also contains chamotte (chamotte in chamotte) and a dense, rich organic solution. Another vessel decorated with three rows of notches made by a straight ornament making tool and underlined by a groove is characterized by the composition of the moulding compound consisting of landwaste and the organic solution with a solid component. A pot with a poorly profiled throat decorated with an ornament in the form of two horizontal rows of notches made by a straight ornament making tool differs by a mixed recipe for the moulding compound consisting of landwaste, chamotte and organic solution, as well as the pot with a grid on a throat.

According to the designing methods, we can allocate at least two skills: the collection contains both vessels made on a mould and vessels made in the shape of a container, which demonstrates the coexistence of two independent methods of designing that existed within the same cultural tradition. However, the basis of designing, which is common to all products, is the scrappy stickingon presented in two variants: the unorganized and the one with spiral overlaying. We can also note that knocking-out with a beater with waffle cutting is characteristic for the $1^{\text {st }}$ variant of ornamentation, and for the $2^{\text {nd }}$ variant - both knocking-out with a beater with waffle cutting and knocking-out of vessels with a spatula wrapped with a twisted cord.

\section{Conclusions}

Thus, the study of the ceramic production technology allows us to see the predominance of mixed skills in the manufacture of ceramic vessels, which is evident by the usage of a mixture of two clays as the raw materials and the prevalence of mixed recipes for the moulding 
compounds. The same is with the skills of designing and shaping of vessels possessed by inhabitants of the Zaostrovka-2 settlements, which may reflect the complex processes of mixing of the ancient people, in the frameworks of which formed the Shepilevsky culture of the late Bronze Age in the Southern taiga zone of the Middle Yenisei.

\section{References}

1. Abdulina Yu.A. Stoyanka bronzovogo veka kompleksa Ust'Shilka-2 na Srednem Yeniseye [A site of the Ust-Shilka-2 complex on the Middle Yenisei in the Bronze Age] Science, education in the culture system: Siberia and Russia: introduction, development, prospects: Proceedings of the $4^{\text {th }}$ AllRussian Scientific Conference. Krasnoyarsk: Publishing house of KrasGAU, 2006, pp. 380-381.

2. Abdulina Yu.A., Mandryka P.V. Novoe poseleniye pozdnego bronzovogo veka v yuzhnoy taiga Srednego Yeniseya [A new settlement in the Southern taiga of the Middle Yenisei in the Late Bronze Age] Proceedings of the laboratory of ancient technologies. Irkutsk: Publishing House of the Irkutsk State Technical University, 2007. Vol. 5, pp. 168-175.

3. Bobrinsky A.A. Goncharstvo Vostochnoy Evropy [Eastern Europe Pottery]. Sources and methods of study. Moscow: Nauka, 1987. 272 p.

4. Bobrinsky A.A. Goncharnaya tekhnologiya kak ob'ekt istoriko-kulturnogo izucheniya [Potter technology as an object of the historical and cultural study] Actual problems of the study of ancient pottery (collective monograph). Samara: Publishing house of SamGPU, 1999. 233 p. P. 5-109.

5. Mandryka P.V. K voprosu o vydelenii novoy kultury bronzovogo veka v taige Priyeniseyskoy Sibiri [On the question of the allocation of a new culture of the Bronze Age in the taiga of the Yenisei Region, Siberia] Time and culture in the archaeological and ethnographic studies of ancient and modern societies of Western Siberia and adjacent territories: problems of interpretation and reconstruction: Proceedings of the West Siberian Archaeological and Geographic Conference. Tomsk: Publishing house Agraf Press, 2008. P. 140-145.

6. Titova Yu.A. (1). Predstavleniye nositeley shepilevskoy kultury o printsipakh otbora iskhodnogo Syria dlya izgotovleniya keramicheskikh sosudov (po materialam poseleniya Zaostrovka-2) [The idea of carriers of the Shepilevsky culture about the principles of selection of raw materials for the manufacture of ceramic vessels (based on the materials of the Zaostrovka-2 settlement)] Culture as a system in its historical context: The experience of West Siberian archaeological and ethnographic meetings: Proceedings of the $15^{\text {th }}$ Anniversary West Siberian Archaeological and Ethnographic Conference. Tomsk: Publishing House of Tomsk State University, 2010. 425 p. P. 78-83.

7. Titova Yu.A. (2). Organika $v$ sostave formovochnykh mass keramicheskikh sosudov shepilevskoy kultury [Organics in the composition of the molding compounds of ceramic vessels of the Shepilevsky culture] Antiquities of the Yenisei Region, Siberia: collection of research papers. Krasnoyarsk: Siberian Federal University, 2012. Vol. 5.97 p. P. 82-84. 


\section{Особенности изготовления керамических сосудов \\ шепилевской культуры}

(по материалам поселения Заостровка-2)

Ю.А. Титова

Сибирский федеральный университет Россия, 660041, Красноярск, пр. Свободный, 79

В статье отражены результаты изучения технологии изготовления керамики позднего бронзового века шепилевской культуры по материалам поселения Заостровка-2. В основе изучения керамической технологии лежит историко-культурный подход и методика А.А. Бобринского. В результате изучения всех стадий керамического производства было установлено преобладание смешанных навыков, являюшихся отражением сложного взаимодействия древнего населения Средней Сибири, в рамках которого происходило формирование шепилевской археологической культуры.

Ключевые слова: археология, керамика, Средняя Сибирь, поздний бронзовый век, иепилевская культура, гончарная технология, историко-культурный подход, исходное сырье, формовочные массы, конструирование, формообразование, обработка поверхности, обжиг.

Научная специальность: 07.00.00-исторические науки. 